\title{
Nano-inspired oxygen barrier coatings for food packaging applications: An overview
}

\author{
Cesare Rovera $^{\mathrm{a}}$, Masoud Ghaani ${ }^{\mathrm{a}}$, Stefano Farris ${ }^{\mathrm{a}, \mathrm{b}, *}$ \\ a DeFENS, Department of Food, Environmental and Nutritional Sciences, Food Packaging Lab, University of Milan, via Celoria 2, I-20133, Milan, Italy \\ ${ }^{\mathrm{b}}$ INSTM, National Consortium of Materials Science and Technology, Local Unit University of Milan, via Celoria 2, I-20133, Milan, Italy
}

\section{Background}

\subsection{Oxygen and food}

The role of oxygen in the packaging and shelf life of foods is twofold. For certain types of foods, oxygen is necessary to avoid rapid aging and senescence of the matrix. This is the case, for example, of fresh fruits and vegetables, which have a respiratory metabolism. However, in most circumstances, it is not harsh to say that oxygen is regarded as the main enemy for several food products. It represents the primary factor of chemical degradation for many matrices, because it is involved in several detrimental reactions. Presence of oxygen in food packages leads to rapid spoilage of food due to rapid oxidation (oxidative rancidity) of fats or vitamins present in food, or by promoting the growth of microorganisms like aerobic bacteria, yeasts and moulds (Dey \& Neogi, 2019).

Additional negative effects caused by the presence of oxygen concern enzymatic systems. Lipases are lipolytic enzymes that provoke hydrolytic rancidity, which involves the cleavage of free fatty acids from triglyceride molecules. Polyphenol oxidases are enzymes that, in the presence of oxygen, may catalyze the browning of vegetable tissues. Laccases may cause color changes in juices and drinks, using oxygen as a second substrate for the enzymatic action.

All the above degradation reactions due to the presence of oxygen eventually lead to discolorations, off-flavors, and sometimes-toxic substances, which may decrease the nutritional value and reduce the shelf life of foods, as well as pose safety threats for consumers. Ultimately, oxygen can be considered as one of several factors that indirectly contribute to increasing food losses and economic damage along the food supply chain. For this reason, controlling the amount of oxygen inside the package (i.e., oxygen in contact with the food) is one of the main targets in the food industry.

\subsection{The role of packaging: conventional coating solutions}

Among other strategies (e.g., modified atmosphere packaging, oxygen scavengers, and antioxidant release systems), limiting the extent of the detrimental reactions linked to the presence of oxygen can be achieved by using a proper packaging configuration that acts as a barrier to oxygen transmission. Historically, early oxygen barrier materials included glass and tinplate, followed by aluminum to produce, for example, cans. All of these provide a total barrier not only to oxygen but to water vapor and, in the case of tinplate and aluminum, to light. However, tinplate and aluminum do not allow seeing through the package, which is a highly sought property for marketing goals. Despite some advantages, these materials exhibit some limitations owing to their inherent nature. For example, the heaviness of glass and tinplate represents a logistical limit at both the economic and environmental levels, whereas multilayer aluminum-based packages are difficult to recycle, which is one reason why landfill sites and incineration are still the most common means of disposal (Garcia, Shin, \& Tae Kim, 2018; Kaiser, Schmid, \& Schlummer, 2018).

Plastic packages obtained coupling materials of different properties (by, e.g., lamination or coextrusion) have represented a versatile solution for several applications, achieving multifunctionality at a relatively low cost. However, this approach requires the manufacturing of "heavy" configurations, which include several layers (up to 15 layers in some circumstances), with a high environmental impact. Coating technology has represented the most efficient and affordable solution to achieve high oxygen barrier performance while using light packaging materials, especially in the case of polyolefins (e.g., polyethylene and polypropylene), which are very poor barriers against oxygen (Farris, 2018). Over the last 60 years, researchers have developed coatings with outstanding performance in terms of oxygen barrier properties.

Polyvinylidene chloride (PVdC), better known under the trade name of $\operatorname{Saran} \AA$, is used in forms that include organic solvent and aqueous

\footnotetext{
* Corresponding author. DeFENS, Department of Food, Environmental and Nutritional Sciences, Food Packaging Lab, University of Milan, via Celoria 2, I-20133, Milan, Italy. E-mail addresses: cesare.rovera@unimi.it (C. Rovera); masoud.ghaani@unimi.it (M. Ghaani); stefano.farris@unimi.it (S. Farris)
} 
dispersions. Its unique performance over all organic polymer coatings relies on simultaneous barrier properties against oxygen and water vapor. More specifically, market-available oxygen barrier PVdC coating aqueous dispersions for food packaging applications have oxygen transmission rate (OTR) values of $\sim 6 \mathrm{~mL} \mathrm{~m}^{-2}$. day ${ }^{-1}$ (i.e., oxygen permeability (OP) of $\sim 90 \mathrm{~mL} \mu \mathrm{m} \cdot \mathrm{m}^{-2}$. $\mathrm{day}^{-1}$ ) at $23^{\circ} \mathrm{C}, 50 \% \mathrm{RH}$, and $1 \mathrm{~atm}$ partial pressure difference $\left(3 \mathrm{~g} \mathrm{~m}^{-2} \mathrm{PVdC}\right.$ coating on polyethylene terephthalate (PET) film of $12 \mu \mathrm{m}$ thick), which is twentyfold lower than the permeability of the neat substrate (PET $12 \mu \mathrm{m}$ thick, OTR $\sim 120 \mathrm{~mL} \mathrm{~m}{ }^{-2} \cdot$ day $^{-1} \equiv \mathrm{OP} \sim 1440 \mathrm{~mL} \mu \mathrm{m} \cdot \mathrm{m}^{-2} \cdot$ day $^{-1}$ at $23^{\circ} \mathrm{C}$, $50 \% \mathrm{RH}$, and $1 \mathrm{~atm}$ partial pressure difference). However, the use of PVdC is being gradually restricted from many packaging structures, due to the dioxins dumped into the air after its incineration.

Ethylene vinyl alcohol (EVOH) is an ethylene and vinyl alcohol copolymer produced by the hydrolysis of ethylene vinyl acetate (EVA). As a rule, the barrier against oxygen increases for the highest degree of hydrolysis. EVOH coatings used in food and beverage packaging are produced from copolymers with $27-47 \%$ ethylene. Nowadays, uses of EVOH mainly concern coating applications in the food and beverage packaging industry, where it allows the achievement of OTR values of approximately $1 \mathrm{~mL} \mathrm{~m}^{-2}$.day ${ }^{-1}$ (i.e., OP of $\sim 14 \mathrm{~mL} \mu \mathrm{m} \cdot \mathrm{m}^{-2} \cdot$ day $^{-1}$ ) at $23{ }^{\circ} \mathrm{C}, 50 \% \mathrm{RH}$, and $1 \mathrm{~atm}$ partial pressure difference $\left(2 \mathrm{~g} \mathrm{~m}^{-2} \mathrm{EVOH}\right.$ coating on PET film of $12 \mu \mathrm{m}$ thick), thus representing an alternative to PVdC coatings. However, practical uses of EVOH are strongly affected by its partially-hydrophilic nature, which increases in an inverse proportion to the ethylene content. For this reason, EVOH coatings lose their oxygen barrier performance at high relative humidity values $(\sim 70 \%)$, making mandatory the use of EVOH between two water vapor barrier materials (e.g., polyolefins).

Poly vinyl alcohol (PVOH) is obtained from the hydrolysis of poly vinyl acetate (PVA). The lack of the ethylene unit along its backbone makes PVOH more hydrophilic than EVOH. For this reason, PVOH coatings act better as a barrier against oxygen, while being more sensitive to the surrounding relative humidity. Under dry conditions, $\mathrm{PVOH}$ coatings exhibit OTR values $\sim 0.4 \mathrm{~mL} \mathrm{~m}^{-2}$.day ${ }^{-1}$ (i.e., OP of $\sim 5.6 \mathrm{~mL} \mu \mathrm{m} \cdot \mathrm{m}^{-2}$. $\mathrm{day}^{-1}$ ) at $23{ }^{\circ} \mathrm{C}, 0 \% \mathrm{RH}$, and $1 \mathrm{~atm}$ partial pressure difference $\left(2 \mathrm{~g} \mathrm{~m}^{-2}\right.$ PVOH coating on PET film of $12 \mu \mathrm{m}$ thick), whereas lab scale-manufactured PVOH films $(60 \pm 1 \mu \mathrm{m})$ under the same conditions gave an OTR value of $5.91 \mathrm{~mL} \mathrm{~m}^{-2}$.day ${ }^{-1}$ (i.e., OP of $\sim 354.6 \mathrm{~mL} \mu \mathrm{m} \cdot \mathrm{m}^{-2} \cdot \mathrm{day}^{-1}$ ) (Lim, Kim, \& Seo, 2016). However, this value is lost starting from RHs above $50 \%$.

Metallization is a physical vapor deposition technique that foresees the deposition of a very thin (a few tenths of $\AA$ ) layer of aluminum on a plastic web by evaporation of solid aluminum wires under high vacuum. Although almost totally impermeable to oxygen (besides other vapors and gases), metallization, which has partially replaced the use of aluminum foil, is increasingly questioned by companies, especially due to the rising demand from companies for transparent packaging films. The advent of the so-called transparent metallization (which involves the deposition of oxidized aluminum as an AlOx transparent coating) seems to have addressed the limitations of the conventional metallization, though a more complex process (PECVD, physical enhanced chemical vapor deposition) and high-cost equipment still hinder the wide use of this technique.

In recent years, the development of new formulations to obtain high oxygen barrier coatings has represented a fervid field of research. This has been primarily due to some main driving forces, such as: the increasing demand of consumers for fresh and minimally processed foods; technical aspects linked to the ultimate performance of the packaging material; economic reasons (the whole packaging cost should not exceed $\sim 10 \%$ of the total cost of the vending unit); market trends (e.g., transparent films); and environmental issues, which have prompted an increasing effort toward more sustainable packaging solutions (Allied Market Research, 2017; Smithers Pira, 2017, 2018). The advent of nanotechnology has opened unprecedented opportunities to create coatings with significantly optimized or enhanced properties for food packaging applications.

\subsection{Nanostructured and nanocomposite coatings}

Most of the current and predicted applications of nanotechnology in the food industry belong to the packaging sector. The commercial market for nano technology in the food and beverage sector was about $\$ 6.5$ billion in 2013 with an annual growth rate of $12.7 \%$ and is likely to reach $\$ 15.0$ billion by 2020 (Naseer et al., 2018). One of the main reason for this lies in the acceptance of consumers for "out-of-food" applications more than "in-food" uses of nanotechnology (Peters et al., 2016). That explains why nanotechnology-based materials and/or devices for food packaging have already found market applications, whereas innovations on food formulation are mainly on a laboratory scale.

Since the early developments in the 1980s, the use of nanotechnology routes has mainly concerned oil-based resins in the form of bulky polymers. Applications of nanoscience principles in the area of coatings intended for food packaging started years later and, in fact, most of the research in this field has been carried out during the last 10 years. Researchers' attention primarily addressed the development of oxygen barrier coatings, for the major role of oxygen on the shelf life of many food products, as discussed in the previous section. Other primary factors of degradation (e.g., light, temperature, moisture), although also important, have often been regarded as of secondary relevance or less suited to be faced by nanotechnology routes. A tentatively exhaustive list of the works on oxygen barrier nano-coatings for food packaging applications over the last decade is displayed in Table 1.

Although the total number of papers is not very high if compared to other sectors (such as electronic, opto-electronic, medical/biomedical, and pharmaceutic), the rising number of publications within the time span considered suggests an increased interest toward "nano" coatings to improve the oxygen barrier performance of packaging materials intended for food preservation (Fig. 1). On one hand, the reason probably lies in the increasingly recognized role of coating technology in pursuing the packaging optimization goal, i.e., down-gauging current packaging structures (e.g., laminates and/or co-extruded materials) without impairing (and, in fact, improving) the overall performance of the substrate beneath, at a reasonable cost (Uysal Unalan, Boyaci, Trabattoni, Tavazzi, \& Farris, 2017). Nanoscience and nanotechnology, on the other hand, will make possible the creation of new functional coatings with previously non-achievable properties (Verma, 2017), with the goal of boosting the never-ending endeavor of meeting the market's needs.

In recent years, two main strategies have been adopted for the generation of "nano" coatings, falling under the so-called bottom-up and top-down headings, respectively. Although a formal definition is lacking, there is general agreement in that while bottom-up routes yield "nanostructured" coatings, top-down approaches lead to "nanocomposite" coatings.

\subsection{Bottom-up approach: nanostructured coatings}

Bottom-up approaches refer to the creation of macroscopic objects/ materials starting from nano-sized species according to hierarchical schemes, where the properties of the final structure depend on the nanoscale effects and organization of the nano-sized architectures. Bottom-up routes involve the manipulation of starting units, which are generally atomic or sub-molecular species. These species, properly manipulated, will form nanoscale components (e.g., clusters, domains) that, in turn, will be included in mesoscale and macroscale materials, e.g., coatings (Fig. 2). 
Table 1

List of works on the development of nanostructured and nanocomposite coatings intended for food packaging applications over the last decade.

\begin{tabular}{|c|c|c|c|c|c|c|}
\hline Approach & Precursor/NBB & Polymer & Substrate & $\begin{array}{l}\text { Coating } \\
\text { method }\end{array}$ & $\begin{array}{l}\text { Oxygen permeability } \\
\left(\mathrm{mL} \cdot \mu \mathrm{m} \cdot \mathrm{m}^{-2} \cdot \mathrm{day}^{-1}\right)\end{array}$ & References \\
\hline Bottom up & $\begin{array}{l}\text { Si-alkoxide, heterometal-alkoxide, } \\
\text { organomodified Si-alkoxide (network } \\
\text { former), organomodified Si-alkoxide } \\
\text { (network modifier) }\end{array}$ & ND & OPP & Roll & $\begin{array}{l}330\left(23^{\circ} \mathrm{C}, 75 \% \mathrm{RH},\right. \\
1 \mathrm{~atm})\end{array}$ & $\begin{array}{l}\text { Haas et al. } \\
\text { (1999) }\end{array}$ \\
\hline Bottom up & $\begin{array}{l}\text { Tetraethyl orthosilicate (TEOS), } \\
\text { 3-isocyanatopropyltriethoxysilane } \\
\text { (ICPTES) }\end{array}$ & $\begin{array}{l}\text { Monohydroxy terminated } \\
\text { polyethylene-block-poly(ethylene } \\
\text { glycol) copolymer }\end{array}$ & LDPE & Spin & $\begin{array}{l}37 \% \text { reduction }\left(35{ }^{\circ} \mathrm{C} \text {, }\right. \\
0 \% \mathrm{RH}) \text { and } 29 \% \\
\text { reduction }\left(50{ }^{\circ} \mathrm{C}, 0 \%\right. \\
\text { RH) compared to } \\
\text { pristine LDPE }\end{array}$ & $\begin{array}{l}\text { Minelli et al. } \\
(2008)\end{array}$ \\
\hline Bottom up & $\begin{array}{l}\text { Tetraethyl orthosilicate (TEOS), } \\
\text { 3-isocyanatopropyltriethoxysilane } \\
\text { (ICPTES) }\end{array}$ & $\begin{array}{l}\text { Monohydroxy terminated } \\
\text { polyethylene-block-poly(ethylene } \\
\text { glycol) } \\
\text { copolymer + poly(4-hydroxystyrene) } \\
\text { (PHS) }\end{array}$ & LDPE & Spin & $\begin{array}{l}50-70 \% \text { reduction } \\
\left(35{ }^{\circ} \mathrm{C} \text { and } 50{ }^{\circ} \mathrm{C}, 0 \%\right. \\
\mathrm{RH}) \text { compared to } \\
\text { pristine LDPE }\end{array}$ & $\begin{array}{l}\text { Toselli et al. } \\
\text { (2008) }\end{array}$ \\
\hline Bottom up & $\begin{array}{l}\text { Tetraethyl orthosilicate (TEOS), } \\
\text { 3-isocyanatopropyltriethoxysilane } \\
\text { (ICPTES) }\end{array}$ & $\begin{array}{l}\text { Poly(caprolactone) (PCL) and } \\
\text { Poly(lactic acid) (PLA) }\end{array}$ & PLA & $\begin{array}{l}\text { Spin } \\
\text { and roll }\end{array}$ & $\begin{array}{l}1950\left(23^{\circ} \mathrm{C}, 0 \% \mathrm{RH},\right. \\
1 \mathrm{~atm})\end{array}$ & $\begin{array}{l}\text { Iotti et al. } \\
(2009)\end{array}$ \\
\hline Bottom up & Tetraethyl orthosilicate (TEOS) & Polyvinyl alcohol (PVOH) & $\begin{array}{l}\text { PET, OPP, CPP, } \\
\text { LLDPE and } \\
\text { LLDPE + LDPE } \\
\text { (blend) }\end{array}$ & $\begin{array}{l}\text { Dip and } \\
\text { roll }\end{array}$ & $\begin{array}{l}\text { Up to two orders of } \\
\text { magnitude compared } \\
\text { to the pristine } \\
\text { substrate }\left(65^{\circ} \mathrm{C}, 0 \%\right. \\
\text { RH) }\end{array}$ & $\begin{array}{l}\text { Minelli et al. } \\
\text { (2010) }\end{array}$ \\
\hline Top-down & $\mathrm{Na}^{+}-\mathrm{MMT}$ & PEI & PET & LbL & $\begin{array}{l}14.32\left(23^{\circ} \mathrm{C}, 0 \% \mathrm{RH},\right. \\
1 \mathrm{~atm})\end{array}$ & $\begin{array}{l}\text { Priolo et al. } \\
\text { (2011) }\end{array}$ \\
\hline Bottom up & Tetraethyl orthosilicate (TEOS) & Pullulan & PET & $\begin{array}{l}\text { Roll } \\
\text { (wire } \\
\text { wound } \\
\text { rod) }\end{array}$ & $\begin{array}{l}12.9\left(23^{\circ} \mathrm{C}, 0 \% \mathrm{RH},\right. \\
1 \mathrm{~atm})\end{array}$ & $\begin{array}{l}\text { Farris et al. } \\
(2012)\end{array}$ \\
\hline Top-down & $\mathrm{Na}^{+}-\mathrm{MMT}$ & Polyacrylamide & PET & LbL & $\begin{array}{l}<\text { instrument } \\
\text { detection limit }\left(23^{\circ} \mathrm{C} \text {, }\right. \\
0 \% \mathrm{RH}, 1 \mathrm{~atm})\end{array}$ & $\begin{array}{l}\text { Jang et al. } \\
(2008)\end{array}$ \\
\hline Top-down & Cellulose nanofibers & ND & PLA & Cast & $\begin{array}{l}25.4\left(23^{\circ} \mathrm{C}, 0 \% \mathrm{RH},\right. \\
1 \mathrm{~Pa})\end{array}$ & $\begin{array}{l}\text { Fukuzumi, } \\
\text { Saito, Iwata, } \\
\text { Kumamoto, } \\
\text { and Isogai } \\
\text { (2009) }\end{array}$ \\
\hline Top-down & Hydrophilic bentonite nanoclay & Chitosan & LDPE & $\begin{array}{l}\text { Roll } \\
\text { (wire } \\
\text { wound } \\
\text { rod) }\end{array}$ & $\begin{array}{l}88 \% \text { reduction }\left(23{ }^{\circ} \mathrm{C},\right. \\
80 \% \mathrm{RH}, 1 \mathrm{~atm})\end{array}$ & $\begin{array}{l}\text { Vartiainen et } \\
\text { al. (2010) }\end{array}$ \\
\hline Top-down & $\mathrm{Na}^{+}$-MMT & $\begin{array}{l}\text { Polyacrylic acid (PAA) and } \\
\text { Polyethylenimine (PEI) }\end{array}$ & PET & LbL & $\begin{array}{l}<\text { instrument } \\
\text { detection limit }\left(23^{\circ} \mathrm{C} \text {, }\right. \\
0 \% \mathrm{RH}, 1 \mathrm{~atm})\end{array}$ & $\begin{array}{l}\text { Priolo et al. } \\
\text { (2010) }\end{array}$ \\
\hline Top-down & TEMPO-oxidized cellulose nanofibrils & ND & PET & Cast & $\begin{array}{l}2.45\left(23^{\circ} \mathrm{C}, 0 \% \mathrm{RH},\right. \\
1 \mathrm{kPa})\end{array}$ & $\begin{array}{l}\text { Fujisawa et } \\
\text { al. (2011) }\end{array}$ \\
\hline Top-down & $\begin{array}{l}\text { Polyethylenimine (PEI) and } \\
\text { Poly(acrylic acid) (PAA) }\end{array}$ & ND & PET & LbL & $\begin{array}{l}<\text { instrument } \\
\text { detection limit }\left(23^{\circ} \mathrm{C},\right. \\
0 \% \mathrm{RH}, 1 \mathrm{~atm}) \\
15.8\left(23^{\circ} \mathrm{C}, 100 \% \mathrm{RH},\right. \\
1 \mathrm{~atm})\end{array}$ & $\begin{array}{l}\text { Yang et al. } \\
\text { (2011) }\end{array}$ \\
\hline Top-down & $\mathrm{Na}^{+}$-MMT & Chitosan & PLA & LbL & $\begin{array}{l}255\left(23{ }^{\circ} \mathrm{C}, 20 \% \mathrm{RH},\right. \\
1 \mathrm{~atm}) \\
635\left(23{ }^{\circ} \mathrm{C}, 50 \% \mathrm{RH},\right. \\
1 \mathrm{~atm})\end{array}$ & $\begin{array}{l}\text { Svagan et al. } \\
(2012)\end{array}$ \\
\hline Top-down & TEMPO-oxidized cellulose nanofibers & ND & PET & Cast & $\begin{array}{l}4\left(23^{\circ} \mathrm{C}, 0 \% \mathrm{RH},\right. \\
1 \mathrm{~atm})\end{array}$ & $\begin{array}{l}\text { Rodionova et } \\
\text { al. (2012) }\end{array}$ \\
\hline Top-down & $\mathrm{Na}^{+}$-MMT & Pullulan & PET & $\begin{array}{l}\text { Roll } \\
\text { (wire } \\
\text { wound } \\
\text { rod) }\end{array}$ & $\begin{array}{l}1.43\left(23{ }^{\circ} \mathrm{C}, 0 \% \mathrm{RH},\right. \\
1 \mathrm{~atm}) \\
258.05\left(23{ }^{\circ} \mathrm{C}^{\circ}, 70 \%\right. \\
\mathrm{RH}, 1 \mathrm{~atm})\end{array}$ & $\begin{array}{l}\text { Introzzi et al. } \\
(2012)\end{array}$ \\
\hline Top-down & Cellulose nanocrystals & Chitosan & PET & LbL & $\begin{array}{l}235\left(23^{\circ} \mathrm{C}, 0 \% \mathrm{RH},\right. \\
1 \mathrm{~atm})\end{array}$ & $\begin{array}{l}\text { Li, Biagioni, } \\
\text { Finazzi, } \\
\text { Tavazzi, and } \\
\text { Piergiovanni } \\
\text { (2013) }\end{array}$ \\
\hline
\end{tabular}




\begin{tabular}{|c|c|c|c|c|c|c|}
\hline Approach & Precursor/NBB & Polymer & Substrate & $\begin{array}{l}\text { Coating } \\
\text { method }\end{array}$ & $\begin{array}{l}\text { Oxygen permeability } \\
\left(\mathrm{mL} \cdot \mu \mathrm{m} \cdot \mathrm{m}^{-2} \cdot \text { day }^{-1}\right)\end{array}$ & References \\
\hline $\begin{array}{l}\text { Bottom- } \\
\text { up + top-down }\end{array}$ & $\mathrm{TEOS}+\mathrm{Na}^{+}-\mathrm{MMT}$ & Pullulan & PET & $\begin{array}{l}\text { Roll } \\
\text { (wire } \\
\text { wound } \\
\text { rod) }\end{array}$ & $\begin{array}{l}0.15\left(23^{\circ} \mathrm{C}, 0 \% \mathrm{RH},\right. \\
1 \mathrm{~atm})\end{array}$ & $\begin{array}{l}\text { Fuentes- } \\
\text { Alventosa et al. } \\
(2013)\end{array}$ \\
\hline Top-down & $\mathrm{Na}^{+}-\mathrm{MMT}$ & PEI & PET & LbL & $\begin{array}{l}16.11\left(23{ }^{\circ} \mathrm{C}, 0 \% \mathrm{RH},\right. \\
1 \mathrm{~atm})\end{array}$ & $\begin{array}{l}\text { Hagen et al. } \\
(2014)\end{array}$ \\
\hline Top-down & $\alpha$-zirconium phosphate ( $\alpha$-ZrP) & Epoxy polymer & PI & $\begin{array}{l}\text { Spray- } \\
\text { coating }\end{array}$ & $\begin{array}{l}285\left(23^{\circ} \mathrm{C}, 0 \% \mathrm{RH},\right. \\
1 \mathrm{~atm})\end{array}$ & $\begin{array}{l}\text { Wong et al. } \\
(2014)\end{array}$ \\
\hline Top-down & LDH & PAA & PET & LbL & $\begin{array}{l}27\left(23^{\circ} \mathrm{C}, 0 \% \mathrm{RH},\right. \\
1 \mathrm{~atm})\end{array}$ & $\begin{array}{l}\text { Dou et al. } \\
(2015)\end{array}$ \\
\hline Top-down & MFC and Borax & Pullulan & ВОРР & $\begin{array}{l}\text { Roll } \\
\text { (wire } \\
\text { wound } \\
\text { rod) }\end{array}$ & $\begin{array}{l}\text { From } 20 \text { to } 100\left(23^{\circ} \mathrm{C},\right. \\
0 \% \mathrm{RH}, 1 \mathrm{~atm})\end{array}$ & $\begin{array}{l}\text { Cozzolino, } \\
\text { Campanella, et } \\
\text { al. (2016) }\end{array}$ \\
\hline Top-down & Colloidal silica & Pullulan & ВОРР & $\begin{array}{l}\text { Roll } \\
\text { (wire } \\
\text { wound } \\
\text { rod) }\end{array}$ & $\begin{array}{l}660\left(23{ }^{\circ} \mathrm{C}, 0 \% \mathrm{RH},\right. \\
1 \mathrm{~atm})\end{array}$ & $\begin{array}{l}\text { Cozzolino, } \\
\text { Campanella, et } \\
\text { al. (2016) }\end{array}$ \\
\hline Top-down & Cellulose nanocrystals & ND & PET & $\begin{array}{l}\text { Roll } \\
\text { (wire } \\
\text { wound } \\
\text { rod) }\end{array}$ & $\begin{array}{l}2.1\left(23^{\circ} \mathrm{C}, 0 \% \mathrm{RH},\right. \\
1 \text { bar }) \\
44.12\left(23{ }^{\circ} \mathrm{C}, 50 \% \mathrm{RH},\right. \\
1 \text { bar })\end{array}$ & $\begin{array}{l}\text { Mascheroni et } \\
\text { al. (2016) }\end{array}$ \\
\hline Top-down & Vermiculite (VMT) & $\begin{array}{l}\text { Polyacrylic acid (PAA) and } \\
\text { Polyethylenimine (PEI) }\end{array}$ & ВОРР & LbL & $\begin{array}{l}30 \text {-fold higher barrier } \\
\text { property compared to } \\
\text { bare BOPP }\left(23^{\circ} \mathrm{C}, 100 \%\right. \\
\mathrm{RH}, 1 \mathrm{~atm})\end{array}$ & $\begin{array}{l}\text { Song et al. } \\
(2016)\end{array}$ \\
\hline Top-down & Nanocellulose (NC) & ND & $\begin{array}{l}\text { Filter paper and } \\
\text { filter mixed with } \\
\text { cellulose ester }\end{array}$ & LbL & $\begin{array}{l}<1.4\left(24{ }^{\circ} \mathrm{C}, 23 \% \mathrm{RH}\right. \\
1 \mathrm{kPa})\end{array}$ & $\begin{array}{l}\text { Herrera et al. } \\
(2016)\end{array}$ \\
\hline Top-down & Graphene oxide (GO) & Pullulan & PET & $\begin{array}{l}\text { Roll } \\
\text { (wire } \\
\text { wound } \\
\text { rod) }\end{array}$ & $\begin{array}{l}51.6\left(23{ }^{\circ} \mathrm{C}^{\circ}, 30 \% \mathrm{RH},\right. \\
1 \mathrm{~atm})\end{array}$ & $\begin{array}{l}\text { Uysal Unalan } \\
\text { et al., } 2016\end{array}$ \\
\hline Top-down & Cellulose nanocrystals & ND & PP & Spin & $\begin{array}{l}39 \% \text { reduction }\left(23.5^{\circ} \mathrm{C} \text {, }\right. \\
0 \% \mathrm{RH}) \text { compared to } \\
\text { pristine PP }\end{array}$ & $\begin{array}{l}\text { d'Eon et al. } \\
(2017)\end{array}$ \\
\hline Top-down & Synthetic mica & Pullulan & PET & $\begin{array}{l}\text { Roll } \\
\text { (wire } \\
\text { wound } \\
\text { rod) }\end{array}$ & $\begin{array}{l}72.6\left(23^{\circ} \mathrm{C}^{\circ}, 30 \% \mathrm{RH},\right. \\
1 \mathrm{~atm})\end{array}$ & $\begin{array}{l}\text { Uysal Unalan } \\
\text { et al., } 2017\end{array}$ \\
\hline Top-down & Cellulose nanocrystals & ND & PET & $\begin{array}{l}\text { Roll } \\
\text { (wire } \\
\text { wound } \\
\text { rod) }\end{array}$ & $\begin{array}{l}1.2\left(30{ }^{\circ} \mathrm{C}, 23 \% \mathrm{RH},\right. \\
1 \text { bar) }\end{array}$ & $\begin{array}{l}\text { Rampazzo et } \\
\text { al. (2017) }\end{array}$ \\
\hline Top-down & Cellulose nanocrystals & ND & PET & $\begin{array}{l}\text { Roll } \\
\text { (wire } \\
\text { wound } \\
\text { rod) }\end{array}$ & $\begin{array}{l}97\left(23^{\circ} \mathrm{C}, 80 \% \mathrm{RH},\right. \\
1 \text { bar) }\end{array}$ & $\begin{array}{l}\text { Fotie et al. } \\
(2017)\end{array}$ \\
\hline Top-down & $\mathrm{Na}^{+}-\mathrm{MMT}$ & PVA & PLA & Dip & $\begin{array}{l}2.05\left(23{ }^{\circ} \mathrm{C}, 0 \% \mathrm{RH},\right. \\
1 \mathrm{~atm})\end{array}$ & $\begin{array}{l}\text { Ding et al. } \\
\text { (2017) }\end{array}$ \\
\hline Top-down & Amino-modified MMT & PVA & PET & Spray & $\begin{array}{l}4\left(23^{\circ} \mathrm{C}, 90 \% \mathrm{RH},\right. \\
1 \mathrm{~atm})\end{array}$ & $\begin{array}{l}\text { Tsurko et al. } \\
(2017)\end{array}$ \\
\hline Top-down & Cellulose nanofibrils (CNFs) & ND & LDPE & $\begin{array}{l}\text { Roll } \\
\text { (wire } \\
\text { wound } \\
\text { rod) }\end{array}$ & $\begin{array}{l}3737\left(23^{\circ} \mathrm{C}, 0 \% \mathrm{RH},\right. \\
1 \mathrm{~atm})\end{array}$ & $\begin{array}{l}\text { Vartiainen et } \\
\text { al. }(2018)\end{array}$ \\
\hline Top-down & $\begin{array}{l}\text { CNFs and lignocellulose nanofibrils } \\
\text { (LCNFs) }\end{array}$ & ND & PHB, PHBV & Spin & $\begin{array}{l}15\left(25^{\circ} \mathrm{C}, 60 \% \mathrm{RH},\right. \\
1 \mathrm{~Pa})\end{array}$ & $\begin{array}{l}\text { Cherpinski et } \\
\text { al. (2018) }\end{array}$ \\
\hline $\begin{array}{l}\text { Top- } \\
\text { down + Bottom- } \\
\text { up }\end{array}$ & $\alpha$-zirconium phosphate $(\alpha-\mathrm{ZrP})$ & $\begin{array}{l}\text { Polyacrylic acid (PAA) and } \\
\text { Poly(dimethyl diallyl } \\
\text { ammonium chloride) } \\
\text { (PDDA) }\end{array}$ & PET & LbL & $\begin{array}{l}22\left(23{ }^{\circ} \mathrm{C}, 0 \% \mathrm{RH},\right. \\
1 \mathrm{~atm})\end{array}$ & $\begin{array}{l}\text { Han et al. } \\
(2018)\end{array}$ \\
\hline Top-down & $\begin{array}{l}\text { Graphene oxide (GO) and amine- } \\
\text { functionalized GO }\end{array}$ & ND & $\mathrm{PE}$ & LbL & $\begin{array}{l}54600 \text { (no specific } \\
\text { thermo-hygrometric } \\
\text { conditions were } \\
\text { indicated by the authors) }\end{array}$ & $\begin{array}{l}\text { Heo et al. } \\
(2019)\end{array}$ \\
\hline
\end{tabular}


Table 1 (Continued)

\begin{tabular}{|c|c|c|c|c|c|c|}
\hline Approach & Precursor/NBB & Polymer & Substrate & $\begin{array}{l}\text { Coating } \\
\text { method }\end{array}$ & $\begin{array}{l}\text { Oxygen permeability } \\
\left(\mathrm{mL} \cdot \mu \mathrm{m} \cdot \mathrm{m}^{-2} \cdot \text { day }^{-1}\right)\end{array}$ & References \\
\hline Top-down & TEMPO-oxidized cellulose nanofibrils & ND & PLA & $\begin{array}{l}\text { Roll } \\
\text { (wire } \\
\text { wound } \\
\text { rod) }\end{array}$ & $\begin{array}{l}\text { 97- and } 23 \text {-fold higher } \\
\text { barrier property } \\
\text { compared to bare PET } \\
\text { and EVOH, respectively }\end{array}$ & $\begin{array}{l}\text { Chowdhury et } \\
\text { al. (2019) }\end{array}$ \\
\hline Top-down & $\begin{array}{l}\text { Cellulose nanofibrils (CNFs) and } \\
\text { cellulose nanocrystals }\end{array}$ & Soy protein & Paper & Cast & $\begin{array}{l}260 \text {-fold higher barrier } \\
\text { property compared to } \\
\text { uncoated paper }\end{array}$ & $\begin{array}{l}\text { Tyagi et al., } \\
2019\end{array}$ \\
\hline Top-down & LDH & ND & PET & $\begin{array}{l}\text { Roll } \\
\text { (wire } \\
\text { wound } \\
\text { rod) }\end{array}$ & $\begin{array}{l}<\text { instrument detection } \\
\text { limit }\left(23^{\circ} \mathrm{C}, 0 \% \mathrm{RH},\right. \\
1 \mathrm{~atm})\end{array}$ & $\begin{array}{l}\text { Yu et al. } \\
(2019)\end{array}$ \\
\hline
\end{tabular}

N.D. Not defined.

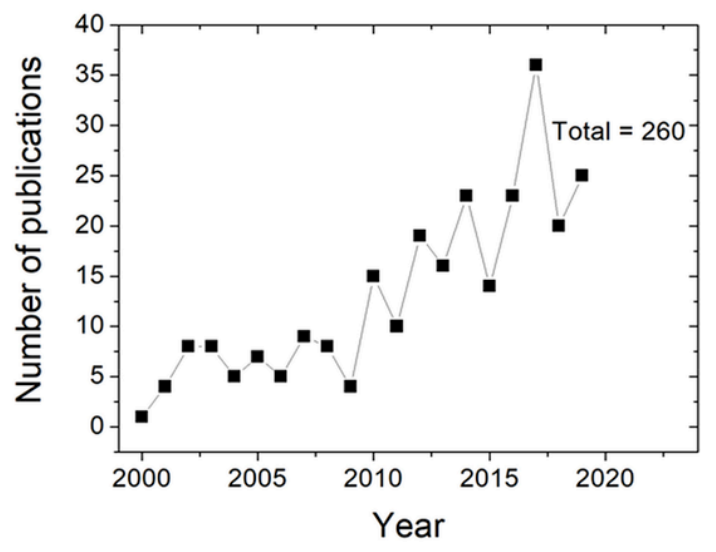

Fig. 1. Publication trends (research articles and review papers) on oxygen barrier coatings for food packaging in the period 2000-2020. The total number is the cumulative sum of publications at the date of the last access to the web. Data for 2020 is for part year (source: Scopus, January 2020).

The goal of scientists is thus to creatively arrange small components into more complex assemblies with useful and sought properties. Such assembly follows two main paths: self-assembly (spontaneous assembly and arrangement of the entities) or directed assembly (the assembly is a guided process by external triggers/pushes) to eventually yield hierarchical structures according to supramolecular chemistry schemes.

The building chemical species used in bottom-up approaches are in most cases represented by metal alkoxide precursors $\mathrm{M}(\mathrm{OR})_{\mathrm{n}}$ or organo-modified metal alkoxide precursors $\mathrm{R}^{\prime}-\mathrm{M}(\mathrm{OR})_{\mathrm{n}-1}$, where $\mathrm{M}$ represents a metal center, $n$ is its oxidation state, RO is a "leaving" (hydrolizable) group, and $\mathrm{R}^{\prime}$ is an organic moiety or functional group covalently linked to the metallic center (Sanchez et al., 2010). Depending on whether the $R^{\prime}$ is a simple non-hydrolyzable group or can react with it- self or other moieties, organo-modified metal alkoxide precursors can be distinguished in network formers and network modifiers, respectively, an example of which is reported in Table 2. With the goal of generating advantageous synergies, hybrid materials are usually developed, i.e., synthetic materials including inorganic and organic components, the latter represented by either an organo-modified precursor or an organic polymer, or both.

Nanostructured coatings using metal alkoxide and organo-modified metal alkoxide precursors are most often obtained by sol-gel chemistry routes. Sol-gel chemistry is widely adopted in the coating technology due to some undisputed advantages. It is an efficient, versatile, cheap, and somehow easier-to-use tool compared to hard-chemistry synthesis approaches. However, these materials are generally amorphous with polydispersed size distributions, and this complexity makes it difficult to study their structure-properties relationships (Nicole, Rozes, \& Sanchez, 2010). Conventional sol-gel reactions involve two main hydrolysis and condensation reactions that lead to the sol, i.e., colloidal size entities suspended in the solvent (water, a hydro-alcoholic solution, or an organic solvent). The manipulation of process parameters (especially $\mathrm{pH}$ of the system, temperature, solvent/precursor molar ratio, etc.) may dramatically affect the shape and arrangement of the entities dispersed in the sol; i.e., individual spheres, branched structures, or tight networks can be obtained. Spontaneous growth of these structures would eventually evolve into macroscopic bodies, namely the gel, which incorporates solvent and residual monomers. In coating technology, a true gel is never obtained, because the sol (or a transitory phase between the sol and the gel) laid onto the substrate (e.g., a plastic web) undergoes drying operations mediated by air, infra-red lamps, UV light, or a combination thereof, leading to the final macroscopic, nanostructured thin layer. Depending on the forces involved at the precursors' interface, hybrid materials are classified as: i) class I hybrids, where the network has been generated by non-permanent forces, such as H-bonds,

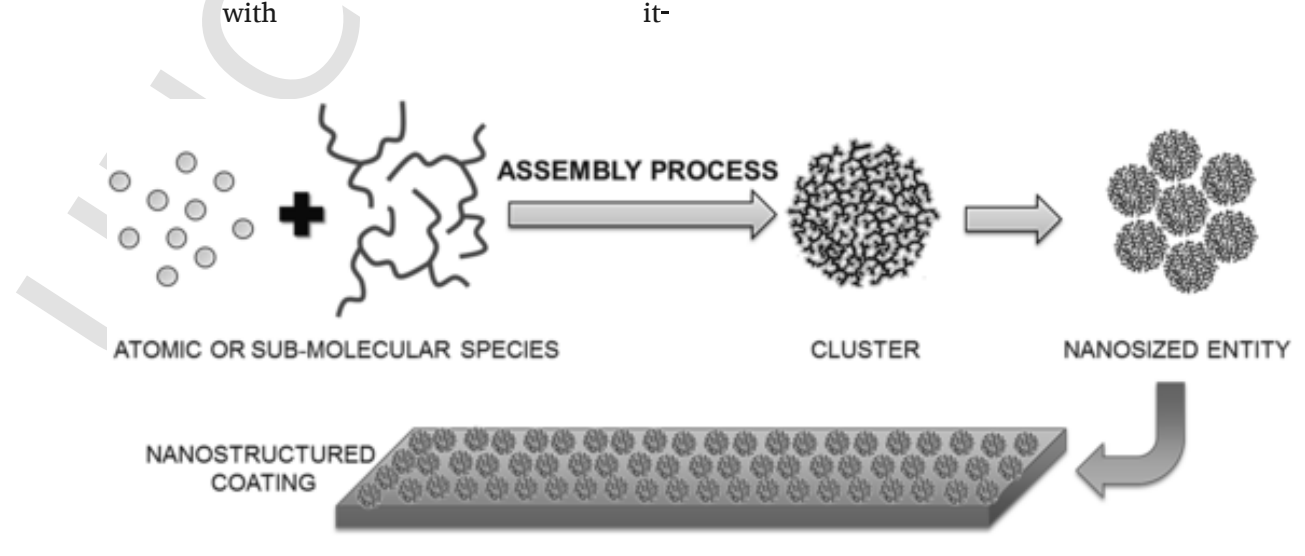

Fig. 2. Schematic representation of a general bottom-up approach for the fabrication of a nanostructured coating. 
Table 2

Examples of network formers and network modifiers precursors used for the fabrication of nanostructured coatings (adapted from Sanchez et al., 2011).

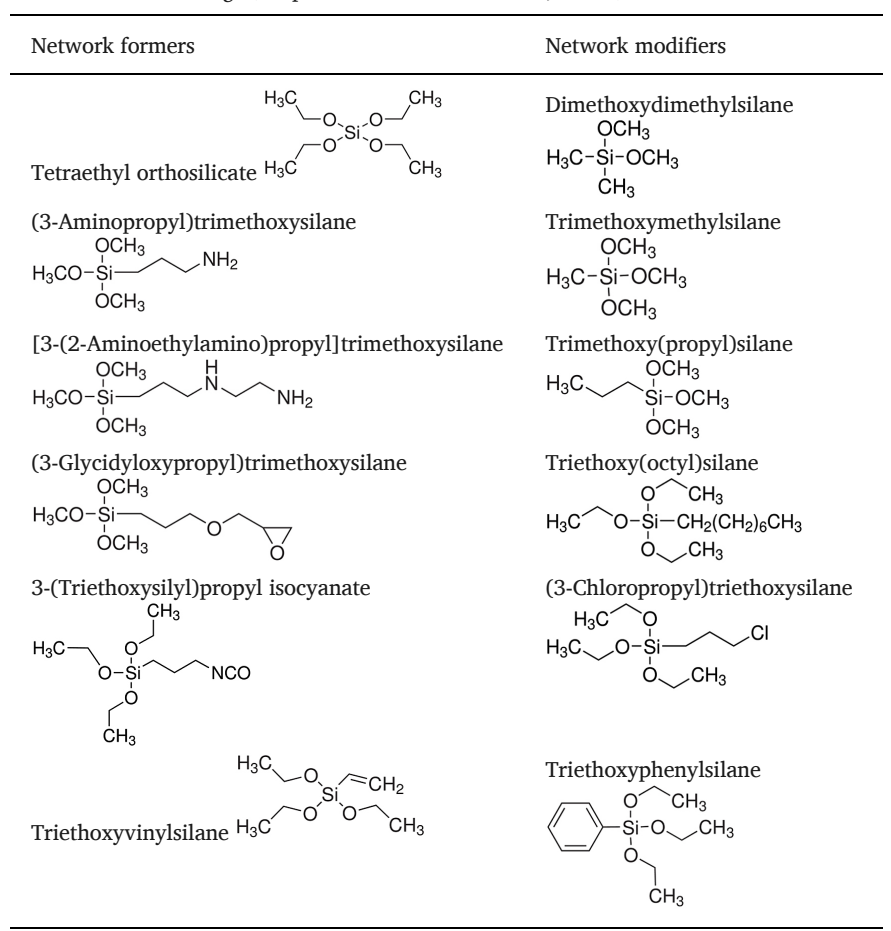

Van der Waals forces, ionic interactions; ii) class II hybrids, which involve the formation of covalent bonds.

As far as nanostructured coatings with intended oxygen barrier properties for food packaging application are concerned, probably the first relevant examples dates back to the end of the 1990, when the Ormocer ${ }^{\circledR}$ (registered trademark of Fraunhofer-Gesellschaft zur Förderung der angewandten Forschung e. V. in Germany) was developed by researchers of Fraunhofer Institute (Haas, Amberg-Schwab, Rose, \& Schottner, 1999). The technology involves a liquid phase processing for coatings that can be deposited on several substrates, e.g., plastic webs, by roll coating, spray coating, dip coating, or spin coating techniques.

Later on, researchers at the University of Bologna used a similar approach to develop hybrid organic-inorganic coatings specifically for food packaging applications. Minelli and co-workers prepared PE-PEG(n)-Si/SiO 2 coatings using tetraethyl orthosilicate (TEOS) as metal alkoxide precursor, 3-isocyanatopropyltriethoxysilane (ICPTES) as network former organo-modified Si-alkoxide and two monohydroxy terminated polyethylene-block-poly(ethylene glycol) copolymers with different ethylene oxide content and molecular weight as organic macromolecules. These hybrid coatings $(0.7-1.0 \mu \mathrm{m})$ were successfully used on LDPE film ( $45 \mu \mathrm{m})$ (Minelli et al., 2008). The same authors observed that the oxygen permeability values could be further decreased by the addition of a second organic polymer (e.g., poly-4-hydroxystyrene) capable of forming hydrogen bonds, thus making the final hybrid coating network tighter (Toselli et al., 2008). Following these findings, in another work Minelli and co-workers used poly vinyl alcohol as an organic phase in combination with TEOS as a metal alkoxide precursor, which was expected to form hydrogen and covalent bonds with the inorganic groups during the synthesis (Minelli, De Angelis, Doghieri, Rocchetti, \& Montenero, 2010). The sol-gel solution was deposited on different plastic polymers that find wide use in the food packaging industry, such as PET, oriented polypropylene (OPP), cast poly(propylene) (CPP), linear LDPE (LLDPE), and a blend of LLDPE and LDPE (COEX).

After the abovementioned early developments, attention toward environmental issues prompted the design of oxygen barrier biopolymer coatings from agricultural and renewable resources, in view of the possibility of replacing commonly used synthetic polymers (e.g., $\mathrm{PVOH}$, EVOH, and PVDC) and managing waste disposal issues (Farris, Introzzi, \& Piergiovanni, 2009). This led to an interesting sub-set of hybrid materials, i.e. the so-called biohybrids, which are materials benefiting simultaneously from the inorganic, organic, and biological areas. One first example of an oxygen barrier biohybrid coating intended for food packaging applications was provided by Iotti and co-workers (Iotti, Fabbri, Messori, Pilati, \& Fava, 2009). In this work, poly(caprolactone) and poly(lactic acid) were used as a compostable organic phase of renewable origin, tetraethyl orthosilicate (TEOS) as metal alkoxide precursor, and 3-isocyanatopropyltriethoxysilane (ICPTES) as network former organo-modified Si-alkoxide. Final hybrid coatings were deposited onto PLA films, which allowed an OTR reduction of $\sim 48 \%$ compared to the bare substrate (uncoated PLA). In another work, Farris and co-workers used pullulan, an exopolysaccharide (EPS) produced by the yeast-like forms of the fungus Aureobasidium pullulans, as the organic phase in combination with TEOS as the inorganic counterpart (Farris et al., 2012). Final biohybrid coatings were laid on a PET film, which yielded a decrease in the final oxygen permeability performance of two orders of magnitude.

Over the years, inherent drawbacks of thin layers obtained by sol-gel approaches (e.g., brittleness, sensitivity to moisture, and somehow tortuous chemical pathways) have relented the development of nanostructured oxygen barrier coatings to the advantage of nanocomposite materials.

\subsection{Top-down approach: nanocomposite coatings}

Nanocomposites represent one of the most successful achievements of nanotechnology in the field of food packaging (Ntim \& Noonan, 2017). In contrast to composites, i.e., mixtures of polymers with inorganic or organic additives having micron-length scale, nanocomposites specifically refer to entities having dimensions in the nano-length scale. These entities, more often known as fillers, are objects with well-defined geometries, such as fibers, flakes, spheres, and particulates. They are produced by a "top-down" approach, which consists of a progressive reduction in size of the parental macro-object. This can be achieved by means of mainly physical routes, such as grinding, milling, etching, ultrasonication, lithography, or precision engineering (Kumar \& Sinha Ray, 2018). Technically speaking, fillers (both of inorganic and organic origin) work as nanobuilding blocks (NBB) that keep their integrity in the final nanocomposite materials (e.g., coatings), where they can arrange in the form of clusters, nano-core shells, organically pre- or post-functionalized nanoparticles (e.g., metal oxides), and layered compounds (e.g., clays) (Sanchez, Belleville, Popall, \& Nicole, 2011) (Fig. 3). The advent of nanocomposites opened up the way to new materials with unprecedented performance. Nanocomposites indeed offer several advantages over the conventional "micro" and "macro" polymer composites. If adequately handled and manipulated, nanocomposite materials provide thermal resistance, mechanical strength, integrity against scratch and abrasion, and a barrier against gases and vapors while exhibiting low density, transparency, good flow, better surface properties, and recyclability even at very low filler contents (generally lower than 5 wt \%) (Sorrentino, Gorrasi, \& Vittoria, 2007).

Although the development of nanocomposite materials included, for the most part, polymers from oil, more recently a new subclass of nanocomposite materials has appeared in line with increasing attempts 


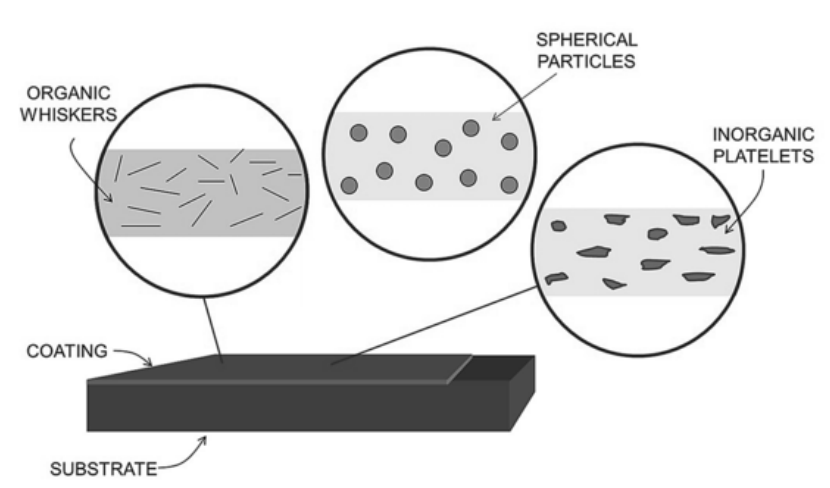

Fig. 3. Types of nano-sized entities that work as nanobuilding blocks (NBBs) in the final nanocomposite coating.

to find an adequate replacement to oil-based polymers with polymers partially or totally obtained from renewable resources (Uysal Unalan, Cerri, Marcuzzo, Cozzolino, \& Farris, 2014). Bionanocomposites refer to those systems where the polymer incorporating the nano-sized filler is of natural origin - directly extracted from biomass (e.g., polysaccharides and proteins), or obtained by synthetic (e.g., poly-lactic acid, PLA) or biotechnological (pullulan, poly-hydroxyalkanoates-PHAs) routes. The addition of NBBs to biopolymers, in particular, offers new opportunities to overcome the typical shortcomings of natural polymers, such as inadequate mechanical and thermal properties, poor resistance to moist environments, and unsatisfactory barrier properties to gas and vapors. The development of bionanocomposites has thus drawn considerable attention in recent years due to the enormous potential of these materials for several applications, including food packaging.

With reference to the oxygen barrier performance, the addition of NBBs reduces the oxygen permeability due to two main reasons: i) according to the "tortuosity path" concept, the impermeable filler represents a physical barrier to the permeant transfer across the material's thickness, thus reducing the diffusion coefficient (Silvestre, Duraccio, \& Cimmino, 2011); ii) according to the "interface effect" concept, fillers with high surface area (e.g., $700-800 \mathrm{~m}^{2} \mathrm{~g}^{-1}$ ) promote local changes in the polymer matrix properties at the interfacial regions (Duncan, 2011). In particular, the higher the extent of the cooperative forces at the filler/polymer interface, the lower the segmental mobility of the molecules.

Historically, the use of NBBs has mainly concerned their incorporation directly into the bulky polymer rather than into thin layers and coatings. The most relevant works found in the literature on the development of oxygen barrier nanocomposite coatings intended for the food packaging sector are reported in Table 1 . This number has increased over recent years, demonstrating the rising interest toward nanocomposite coatings with enhanced oxygen barrier performance.

A rapid and easy-to-scale approach for the preparation of oxygen barrier nanocomposite coatings is based on 1-step deposition of the functional layer. If the nanocomposite system is solvent-based, the assembly of polymer and NBBs will be driven by solvent evaporation. The deposition of the nanocomposite coating solution or dispersion at lab scale is chiefly made by wire wound metering rods or spin coating techniques, whereas roll-to-roll techniques (e.g., gravure coating) are mostly employed at industrial scale.

Cellulose and its derivatives (e.g., cellulose nanofibrils and cellulose nanocrystals) have been extensively used as organic NBBs to develop high oxygen barrier coatings for food packaging applications, as demonstrated by the relevant numbers of publications (Fukuzumi, Saito, Iwata, Kunamoto, \& Isogai, 2009; Fujisawa, Okita, Fukuzumi, Saito, \& Isogai, 2011; Rodionova et al., 2012; Fujisawa et al., 2011; Mascheroni et al., 2016; Herrera, Sirviö,
Mathew, \& Oksman, 2016; d'Eon, Zhang, Chen, Berry, \& Zhao, 2017; Rampazzo et al., 2017; Fotie et al., 2017; Vartiainen, Pasanen, Kenttä, \& Vähä-Nissi, 2018; Cherpinski et al., 2018; Chowdhury et al., 2019; Tyagi, Lucia, Hubbe, \& Pal, 2019). The reason for this increasing interest lies in both the outstanding functional properties and the natural origin of this biopolymer, which well fits with the rising need for green approaches and biodegradable and compostable materials intended for the food sector (Rovera et al., 2018).

Inorganic particles have also been used in the fabrication of nanocomposite coatings with high oxygen barrier properties. For example, Vartiainen et al. incorporated bentonite nanoclay in chitosan coatings deposited onto LDPE film (Vartiainen, Tuominen, \& Nättinen, 2010), whereas natural montmorillonite $\left(\mathrm{Na}^{+}-\mathrm{MMT}\right)$ was incorporated in pullulan with the goal of improving the oxygen barrier properties of PET even at high RH conditions (Introzzi et al., 2012). Fuentes Alventosa and co-workers creatively combined the two concepts of bottom-up and top-down to develop nanostructured biohybrid coatings by an integrated "sol-gel-intercalation" approach (Fuentes-Alventosa et al., 2013), whereby TEOS and $\mathrm{Na}^{+}-\mathrm{MMT}$ (used as metal alkoxide precursor and inorganic NBB, respectively) were incorporated in pullulan yielding a final nanocomposite and nanostructured network by in-situ self-assembly.

Platy NBBs as alternative to montmorillonites were used for the development of oxygen barrier nanocomposite coatings intended for food packaging applications. Unalan et al., for example, tested the oxygen barrier performance of nanocomposite coatings obtained using GO and synthetic mica as fillers (Uysal Unalan, Boyaci, Ghaani, Trabattoni, \& Farris, 2016; Uysal Unalan et al., 2017). The authors proved the outstanding performance of the nanocomposite coating under dry conditions (OTR values below the instrumental detection limit) for both fillers. However, this performance was almost totally lost at high RHs ( $90 \% \mathrm{RH})$ due to what the same authors defined as the "diluting" effect of water molecules.

More recently, a combination of NBBs with different geometry was tested to produce oxygen barrier nanocomposite coatings. For example, borax (a salt of sodium borate) and microfibrillated cellulose (MFC) were added to the main pullulan coating polymer deposited on BOPP films (Cozzolino, Campanella, Türe, Olsson, \& Farris, 2016). The same research group investigated the potential of round-shape nanoparticles when used to formulate nanocomposite coatings to improve the oxygen barrier performance of plastic films (Cozzolino, Castelli, Trabattoni, \& Farris, 2016). In particular, the influence of two different types of colloidal silica (CS) nanoparticles in a main pullulan coating on BOPP was evaluated with the goal of exploring new and more advantageous applications in the food packaging sector. An improvement in the barrier properties against $\mathrm{O}_{2}$ was observed for all the tested nanocomposite coatings, especially when particles with the highest surface area $\left(750 \mathrm{~m}^{2} \mathrm{~g}^{-1}\right)$ were used. The results obtained in this work confirmed that round-shape particles are less effective than platy NBBs in reducing the oxygen permeability of plastic films, due to the lower surface area per unit weight exposed to the permeation (for a theoretical orientation of the platelets perpendicular to the direction of the permeant diffusion). However, the authors pointed out that this behavior can be advantageously exploited for those foods that require a minimum amount of oxygen to avoid sudden aging and senescence, such as fresh and minimally processed fruits, vegetables, and salads, or fresh cheeses.

In addition to 1-step techniques, other approaches with higher degree of sophistication were proposed for the deposition of the coating on the packaging material. Over the past few decades, layer-by-layer (LbL) assembly of thin films has been of considerable interest because of its ability to exert nanometer control over film thickness and its extensive choice of useable materials for coating planar and particulate 
substrates (Richardson, Bjornmalm, \& Caruso, 2015). The choice of materials allows for responsive and functional thin films to be engineered for various applications, including food packaging. LbL consists in the preparation of a multilayer coating through alternating deposition of colloidal particles of opposite charges (Zhang et al., 2019). After the pioneering works of Jang, Rawson, and Grunlan (2008), whereby alternate layers of sodium montmorillonite clay $\left(\mathrm{Na}^{+}{ }_{-} \mathrm{MMT}\right)$ were assembled with cationic polyacrylamide, other researchers extensively used the same approach to obtain oxygen barrier coatings for food packaging applications. Priolo and co-workers first developed flexible and transparent oxygen barrier coatings based on a nano brick wall structure obtained from the alternate adsorption of polyethylene imine (PEI), polyacrylic acid (PAA), and $\mathrm{Na}^{+}$-MMT (Priolo, Gamboa, Holder, \& Grunlan, 2010). In a similar way, Yang and co-workers used the LbL approach to produce high oxygen barrier coatings by assembling the polycationic PEI and the polyanionic PAA onto PET substrate (175 $\mu \mathrm{m}$ thick) (Yang, Haile, Park, Malek, \& Grunlan, 2011). The same authors worked on PEI and $\mathrm{Na}^{+}$-MMT LbL thin films, investigating the effect of clay concentration (Priolo, Holder, Gamboa, \& Grunlan, 2011) and pH (Hagen, Saucier, \& Grunlan, 2014) in achieving an outstanding oxygen barrier performance through approaching a perfect ordering of the platelets deposited on the substrate. Natural montmorillonite was also used to assemble by LBL alternating layers of montmorillonite clay and chitosan on extruded PLA film surfaces (Svagan et al., 2012).

Though montmorillonite was the most widely used NBB for LbL assembly to obtain oxygen barrier coatings, other inorganic nanoparticles were used to this scope. Layered $\alpha$-zirconium phosphate $(\alpha-\mathrm{ZrP})$ has been successfully incorporated into an epoxy polymer generating a nanocomposite coating deposited on a polyimide (PI) substrate. Final PI films coated with the smectic $\alpha$-ZrP nanoplatelet/epoxy nanocomposite exhibited outstanding oxygen barrier properties (Wong et al., 2014). More recently, $\alpha$-ZrP was used in combination with PAA and poly(dimethyl diallyl ammonium chloride) (PDDA) to yield a quadlayer (QL) assembly that generated a nanobrick wall hybrid coating on PET film (25 $\mu \mathrm{m}$ thick) with super oxygen barrier properties (Han et al., 2018).

Layered double hydroxide (LDH) proved to be a valid option for the generation of transparent high oxygen barrier coatings. LDH were first proposed for food packaging applications by Dou and co-workers, who assembled LDH and PAA obtaining near-perfectly parallel orientation of the LDH "brick" in the PAA "mortar", hence creating a long diffusion length that hinders the transmission of oxygen (Dou et al., 2015). In a recent work, high gas barrier coatings specifically intended for food packaging were developed using LDH deposited on PET substrate (12 $\mu \mathrm{m}$ thick) (Yu et al., 2019). In addition to the outstanding oxygen barrier performance of the final material (see Table 1), this work highlighted the possibility of synthetize LDH using a procedure that allow full compliance of LDH with GMP certification, being LDH recognized as safe (GRAS) and approved for human. Finally, vermiculite (VMT) was also tested in combination with PEI and PAA by LbL assembly on bi-oriented polypropylene (BOPP) (Song, Tzeng, \& Grunlan, 2016).

Very recently, a spray-assisted LbL assembly was used to couple bare graphene oxide (GO) (negatively charged) and amino-functionalized GO (positively charged) (Heo, Choi, \& Hong, 2019). Alternating layers of $\mathrm{GO}-$ and GO + were deposited on PE (50 $\mu \mathrm{m}$ thick) which has no intrinsic gas barrier properties. The most critical drawback associated to the LbL technique is represented by the time consuming rinsing operations between each individual deposition, which seems to be hinder any potential industrial scale up. To overcome this drawback, Dabbaghianamiri and co-workers proposed a simplified version of the LbL approach by an ink-jet printing deposition (Dabbaghianamiri, Das, \& Beall, 2017). According to the authors, this technique is industrially scalable and efficient because it does not need any rinsing step and dry- ing steps as required in conventional LbL. The authors tested several polymer/nanoclay pairs. The best performance was found for the polyvinyl pyrrolidone/montmorillonite assembly, which was indicated as a promising oxygen barrier candidate for a variety of food packaging applications. As an alternative method to LbL, Ding and co-workers developed a facile coassembly process using $\mathrm{Na}^{+}$-MMT and PVA as a main polymer matrix (Ding et al., 2017). According to the authors, the excellent oxygen barrier performance of the PLA films coated with the $\mathrm{Na}^{+}$-MMT nanocomposite coatings is due to the well aligned nanosheets along the substrate surface.

It is important to note that the oxygen barrier performance of the nanocomposite coatings is usually tested under dry conditions (see Table 1). However, this instrumental setting is quite unrealistic, because in most circumstances the packaging material is in contact with a humid environment (either due to the packaged food or to the surrounding environment). For this reason, finding a solution to design oxygen barrier coatings with low sensitivity to humidity is of great importance for future developments. Under this perspective, Tsurko and co-workers suggested that extensive hydrogen bonding between polymer and filler can prevent swelling, hence allowing high oxygen barrier performance of waterborne coatings to be achieved at high RHs (Tsurko et al., 2017). To this scope, the same authors used an amino-modified montmorillonite loaded into a main PVA polymer, achieving remarkable low oxygen permeability values even at $90 \% \mathrm{RH}$. Recent trends also suggest new schemes to control the detrimental effect of humidity on the oxygen barrier properties of water based coatings. Very recently, Merritt and co-workers demonstrated an effective way to facilitate the dispersion and orientation of graphene oxide (GO) nanoplatelets in a polymer matrix through encapsulating the polymer within a nanoplatelet shell (Merritt et al., 2020). In particular, few-layered GO nanoplatelets encapsulated polystyrene (PS) microparticles were synthesized by a Pickering suspension polymerization method, which led to a dramatic increase of the oxygen barrier performance.

Although most developments of oxygen barrier nanocomposite coatings for food packaging applications are still at laboratory level, some formulations are available in the market. For example, InMat Inc. developed Nanolok ${ }^{\mathrm{TM}}$, a high barrier, water-based, environmentally friendly nanocomposite barrier coating for transparent packaging applications. According to the company's specifications, this nanocomposite coating provides an excellent oxygen barrier up to $80 \%$ relative humidity and is more cost effective than EVOH (InMat, 2009). NanoPack Inc. has developed a water-based coating made of $\mathrm{PVOH}$ and vermiculite. This coating, sold under the Nano-Seal ${ }^{\mathrm{TM}}$ trade name, is specifically intended for food packaging applications where protection of food against oxygen and aromas is required (NanoPack, 2012). SAES Coated Films Spa is currently selling a high oxygen barrier coating based on nanotechnology approaches (SAES Coated Films, 2019). The nano-coating is water based and highly transparent, with exceptional oxygen barrier properties even at high relative humidity values. This coating has been successfully tested by Gholami et al. for the design of a new packaging system for white mushroom, allowing the extension of the shelf life up to 21 days at $4{ }^{\circ} \mathrm{C}$ in combination with an appropriate modified atmosphere (Gholami, Ahmadi, \& Farris, 2017).

\section{Safety issues and European legal framework}

The safety concerns about the use of nanocomposite materials for food contact applications rely on physical and chemical properties different than their 'macro' (bulk) counterparts, which translate into a possibly different reactivities towards biological media. The toxicological risk for humans associated with 'nano' packaging materials (such as nanocomposite coatings) strictly depends on two main factors: i) the potential migration of the nanoparticles into food and ii) the toxicological effect of the nanoparticles on humans' health. 
From a legal point of view, the definition of nanomaterial dates back to 2011, when the EU Commission defined one nanomaterial as "a natural, incidental or manufactured material containing particles, in an unbound state or as an aggregate or as an agglomerate and where, for $50 \%$ or more of the particles in the number size distribution, one or more external dimensions is in the size range $1 \mathrm{~nm}-100 \mathrm{~nm}$ " (Recommendation 2011/696/EU) (EU, 2011a). This definition of 'nanomaterial' in EU legislation accounts solely for the size of the particles, with no regard to hazard or risk. In addition, this definition allows discrimination between 'bottom-up' and 'top-down' materials according to the description given in this review. More specifically, bottom-up materials must be intended as a network rather than as an assembly of discrete nanoparticles. Therefore, nanostructured coatings obtained by a bottom-up approach (e.g., sol-gel or plasma-enhanced chemical vapor deposition - PECVD) do not fall into the category of nanomaterials as defined in EU Recommendation 696/2011 because they do not consist of primary particles with defined physical boundaries (Störmer, Bott, Kemmer, \& Franz, 2017). It is thus reasonable to think that nanostructured materials for food contact applications can be used as long as the chemicals used to form or modify the network are authorized according to EU Regulation n. 10/ 2011 (EU, 2011).

The use of nanoparticles for food contact applications is specifically addressed by EU Regulation n. 10/2011 (EU, 2011), which refers generally to 'substances in nanoform'. It is clarified that substances in nanoform may only be used if explicitly authorized and mentioned in the specifications in Annex I of the Plastics Regulation (Article 9). The rationale behind this precautionary approach lies in the fact that nanoparticles may have different physico-chemical properties and therefore different toxicological profiles than larger structured substances (recital (23)).

Therefore, a possible use of nanomaterials is only envisaged if a risk assessment of nanoparticles is performed on a case-by-case basis. It clearly ensues from the above restriction that for 'substances in nanoform' the functional barrier concept does not apply, similarly to substances classified as carcinogenic, mutagenic, or toxic for reproduction (see Article 13, paragraph 4 (b)). The lack of specific legislative rules toward the use of nanoparticles for food contact applications is mostly explained by the still existing gaps in knowledge of the toxicological effects possibly ascribable to nanoparticles. As pointed out by Störmer and co-workers, until today no toxicologically derived thresholds of no concern have been established for nanomaterials, similarly to the threshold of toxicological concern (TTC) concept for molecular substances (Störmer et al., 2017).

In spite of the restrictive and precautionary approach adopted, recent studies have demonstrated that nanoparticles that are completely encapsulated in the host polymer matrix do not have a potential to migrate into food (Bott \& Franz, 2018; Störmer et al., 2017). Thus, consumers will not be exposed to nanoparticles from food contact polymers as long as the particles are completely embedded in the polymers. Störmer and co-workers have pointed out that, especially for platy shapes, 5-nm nanoparticles and larger ones are quasi-immobilized in the polymer to the effect that migration is expected to be negligibly small even at high use levels. However, the same authors stated that the release of the nanoparticles to food might occur in case of mechanical damage or stress of the polymer matrix during the in service life of the packaging material.

A series of exhaustive experiments apparently confirm that, under normal conditions, the migration of conventional nanoparticles from food packaging materials is negligible and increases with decreasing polymer dynamic viscosity and nanoparticle size (Naseer et al., 2018). It has been pointed out that a critical aspect in migration estimation is linked to the limitations of the analytical techniques and, in particular, to the necessity of performing pre-preparation procedures for the accurate quantification of nanoparticles (Bumbudsanpharoke
\& Ko, 2015). This is because functionalities of the nanomaterials can change in different food matrices, depending on compounds and thermodynamic conditions (Huang, Li, \& Zhou, 2015). The risk associated to nanoparticles is accounts for their unique physical properties, such as surface area, size and shape, atomic composition, charge distribution, and state of agglomeration. The enhanced risk of nanoengineered particles is due to their higher reactivity and increased bioavailability of smaller particles to our bodies leading to long-term pathological effects. Ingestion of foods previously in contact with nano-packaging can be an exposure route (Cushen, Kerry, Morris, Cruz-Romero, \& Cummins, 2012). The migration of nanoparticles from food packaging materials and the behavior of nanoparticles possibly entering the body are still being evaluated at an extensive level. Nanoparticles can cause oxidative stress to human body cells and can traverse from lungs to blood, cell nuclei, and central nervous system leading to the inflammation of the gastrointestinal tract, Parkinson's syndrome, Alzheimer's disease, as well as the impairment of the DNA. Adverse effects on kidney, liver, and other vital organs have been reported due to long term exposure to nanoparticles (Naseer et al., 2018).

Not only must the potential adverse effects on the consumer's health, but also the environmental impact of nanoparticle possibly released into the environment (the so called ecotoxicity) be considered to develop appropriate end-of-life management strategies to minimize human and/ or environmental exposure (Part et al., 2018). One key issue to be addressed is to know more about the implications of the nano-composite packaging materials once they become waste (Sànchez, Hortal, Aliaga, Devis, \& Cloquell-Ballester, 2014). Although the release of nanoparticles into the environment can occur naturally (e.g., volcanic eruption) or unintentionally (e.g., vehicle exhaust), nanoparticles can end up in terrestrial and aquatic ecosystems intentionally, e.g. as a consequence of the waste management (e.g., composting, landfilling and incineration). In a recent study by Balaguer and co-workers, it was demonstrated that the ecotoxic effects to higher plants (evaluated in terms of seedling emergence and early growth of higher plants exposed to the compost resulting from disintegradation of the original nanomaterial) of PLA reinforced with three different NBBs (ammonium-modified MMT, calcium carbonate and silicon dioxide) was negligible (Balaguer, Aliaga, \& Hortal, 2016).

\section{Concluding remarks and future trends}

Nanotechnology has shown immense potential in the food packaging sector. The development of smart materials, in particular, has paved the way to unprecedented performance of the final package. The achievement of outstanding oxygen barrier properties, in particular, has been demonstrated over the last decade as one of the most successful applications of nanotechnology to food packaging. Most recently, researchers have been focusing on the development of high oxygen barrier coatings as a way to face the environment impact of packaging materials by reducing the upstream amount of plastics or improving the final performance of plastics from renewable resources. It has also been highlighted the urgent unmet need for scalable solutions that can replace metallized films, allowing easier recycling without separation from the rest of packaging materials. Under this perspective, the production of an oxygen barrier coated film that is comparable to metallized multilayer materials is urgently required to address the many challenges of the circular economy for plastic use ( $\mathrm{Yu}$ et al., 2019). "Nano" coatings possibly made of a main polymer phase of renewable origin (the so called bionanocoatings) may open the way to new solutions toward this direction.

In spite of the excellent performance, nano-inspired coatings are still far from full market penetration. With few exceptions, commercial applications are still lacking, or kept at an immature stage. The reasons for this trend can be manifold. First, nano-coatings are materials with a high degree of sophistication integrated in thin layer (in most cases, 
less than $1 \mu \mathrm{m})$. This means that deep fundamentals of chemistry, physics, and manufacturing aspects of coating technology are necessary to have full access to successful solutions. Second, food packaging applications require multi-functionality. Oxygen barrier performance, although outstanding, is not a sufficient requirement for commercial applications. Transparency, sealability, resistance to moist environment, and sliding on the packaging machinery, just as examples, are parameters to meet in order to fulfill end users' needs. Unfortunately, this multi-functionality is not as easy as it might seem. Third, some technical drawbacks still need to be addressed, such as brittleness and lack of adhesion to the plastic substrate, which concurrently may affect the mechanical stability of the coating. Moreover, to achieve a true nanocomposite polymer system with improved oxygen barrier properties compared to conventional microcomposites, the filler must be uniformly dispersed and not aggregated. In other words, it is of utmost importance to obtain an ordered alignment of the nanoparticles (especially if of platy shape) within the coating thickness in order to maximize the advantage arising from the high surface area of the filler. Another issue hindering market applications is linked to the final cost of the packaging. Due to the technology involved, high-performance nano-coatings often account for a high amount of the whole cost of the final package. However, for most food products, the packaging cost should not exceed $\sim 10-15 \%$ of the total cost of the goods placed on the shelves. Another important aspect is legislation. Current EU regulation on plastic materials intended to come into contact with food (specifically Reg. 10/2011) clearly states that the use of nanomaterials is restricted to case-by-case assessments, i.e., provided that no migration is unambiguously demonstrated by the business operator by an appropriate documentation. That documentation must contain the conditions and results of testing; calculations, including modelling; other analyses; and evidence on the safety or reasoning demonstrating compliance. In fact, not all coating manufacturers can afford such a heavy path, especially from an economic perspective.

\section{Declaration of interest}

The authors declare that they have no conflict of interest.

\section{Uncited references}

\section{Acknowledgment}

This research did not receive any specific grant from funding agencies in the public, commercial, or not-for-profit sectors.

\section{References}

d'Eon, J., Zhang, W., Chen, L., Berry, R. M., \& Zhao, B. (2017). Coating cellulose nanocrystals on polypropylene and its film adhesion and mechanical properties. Cellulose, 24, 1877-1888.

Allied Market Research Packaging coatings markethttps://www.alliedmarketresearch. com/packaging-coatings-market2017last access: November 2019

Balaguer, M. P., Aliaga, C., \& Hortal, M. (2016). Compostability assessment of nano-reinforced poly(lactic acid) films. Waste Management, 48, 143-155.

Bott, J., \& Franz, R. (2018). Investigation into the potential migration of nanoparticles from laponite-polymer nanocomposites. Nanomaterials, 8, 723-735.

Bumbudsanpharoke, N., \& Ko, S. (2015). Nano-food packaging. An overview of market, migration research, and safety regulations. Journal of Food Science, 80, R910-R923.

Cherpinski, A., Torres-Giner, S., Vartiainen, J., Peresin, M. S., Lahtinen, P., \& Lagaron, J. M. (2018). Improving the water resistance of nanocellulose-based films with polyhydroxyalkanoates processed by the electrospinning coating technique. Cellulose, 25, 1291-1307.

Chowdhury, R. A., Nuruddin, M., Clarkson, C., Montes, F., Howarter, J., \& Youngblood, J. P. (2019). Cellulose nanocrystal (CNC) coatings with controlled anisotropy as high-performance gas barrier films. ACS Applied Materials and Interfaces, 11, 1376-1383.

Cozzolino, C. A., Campanella, G., Türe, H., Olsson, R. T., \& Farris, S. (2016). Microfibrillated cellulose and borax as mechanical, $\mathrm{O}_{2}$-barrier, and surface-modulating agents of pullulan biocomposite coatings on BOPP. Carbohydrate Polymers, 143, 179-187.
Cozzolino, C. A., Castelli, G., Trabattoni, S., \& Farris, S. (2016). Influence of colloidal silica nanoparticles on pullulan-coated BOPP film. Food Packaging and Shelf Life, 8, 50-55.

Cushen, M., Kerry, J., Morris, M., Cruz-Romero, M., \& Cummins, E. (2012). Nanotechnologies in the food industry - recent developments, risks and regulation. Trends in Food Science \& Technology, 24, 30-46.

Dabbaghianamiri, M., Das, S., \& Beall, G. W. (2017). Improvement approach for gas barrier behavior of polymer/clay nanocomposite films. MRS Advances, 2, 3547-3552.

Dey, A., \& Neogi, S. (2019). Oxygen scavengers for food packaging applications: A review. Trends in Food Science \& Technology, 90, 26-34.

Ding, F., Liu, J., Zeng, S., Xia, Y., Wells, K. M., \& Nieh, M.-P., et al. (2017). Biomimetic nanocoatings with exceptional mechanical, barrier, and flame-retardant properties from large-scale one-step coassembly. Science Advances, 3, e1701212.

Dou, Y., Pan, T., Xu, S., Yan, H., Han, J., \& Wei, M., et al. (2015). Angewandte Chemie International Edition, 54, 9673-9678.

Duncan, T. V. (2011). Applications of nanotechnology in food packaging and food safety: Barrier materials, antimicrobials and sensors. Journal of Colloid and Interface Science, $363,1-24$

EU (2011). Commission recommendation of 18 October 2011 on the definition of nanomaterial (2011/696/EU). Official Journal of the European Union, 275, 38-40.

EU (2011). Commission Regulation (EU) No 10/2011 of 14 January 2011 on plastic materials and articles intended to come into contact with food. Official Journal of the European Union, 1-89. L12/1.

Farris, S. (2018). Engineering properties of packaging films. In Siddiqui, M. W., Rahman, M. S., \& Wani, A. A. (Eds.), Innovative packaging of fruits and vegetables: Strategies for safety and quality maintenance (pp. 211-226). Waretown, New Jersey: Apple Academic Press.

Farris, S., Introzzi, L., Fuentes-Alventosa, J. M., Santo, N., Rocca, R., \& Piergiovanni, L. (2012). Self-assembled pullulan-silica oxygen barrier hybrid coatings for food packaging applications. Journal of Agricultural and Food Chemistry, 60, 782-790.

Farris, S., Introzzi, L., \& Piergiovanni, L. (2009). Evaluation of a bio-coating as a solution to improve barrier, friction and optical properties of plastic films. Packaging Technology and Science, 22, 69-83.

Farris, S., \& Piergiovanni, L. (2012). Emerging coating technologies for food and beverage packaging materials. In Yam, K. L., \& Lee, D. S. (Eds.), Emerging food packaging technologies: Principles and practice (p. 276). Oxford: Woodhead Publishing Ltd.

Fotie, G., Rampazzo, R., Ortenzi, M. A., Checchia, S., Fessas, D., \& Piergiovanni, L. (2017). The effect of moisture on cellulose nanocrystals intended as a high gas barrier coating on flexible packaging materials. Polymers, 9, 415.

Fuentes-Alventosa, J. M., Introzzi, L., Santo, N., Cerri, G., Brundu, A., \& Farris, S. (2013). Self-assembled nanostructured biohybrid coatings by an integrated "sol-gel/intercalation" approach. RSC Advances, 3, 25086-25096.

Fujisawa, S., Okita, Y., Fukuzumi, H., Saito, T., \& Isogai, A. (2011). Preparation and characterization of TEMPO-oxidized cellulose nanofibril films with free carboxyl groups. Carbohydrate Polymers, 84, 579-583.

Fukuzumi, H., Saito, T., Iwata, T., Kumamoto, Y., \& Isogai, A. (2009). Transparent and high gas barrier films of cellulose nanofibers prepared by TEMPO-mediated oxidation. Biomacromolecules, 10, 162-165.

Garcia, C. V., Shin, G. H., \& Tae Kim, J. (2018). Metal oxide-based nanocomposites in food packaging: Applications, migration, and regulations. Trends in Food Science \& Technology, 82, 21-31.

Gholami, R., Ahmadi, E., \& Farris, S. (2017). Shelf life extension of white mushrooms (Agaricus bisporus) by low temperatures conditioning, modified atmosphere, and nanocomposite packaging material. Food Packaging and Shelf Life, 14, 88-95.

Haas, K.-H., Amberg-Schwab, S., Rose, K., \& Schottner, G. (1999). Functionalized coatings based on inorganic-organic polymers (ORMOCER $\AA s)$ and their combination with vapor deposited inorganic thin films. Surface and Coatings Technology, 111, 72-79.

Hagen, D. A., Saucier, L., \& Grunlan, J. C. (2014). Controlling effective aspect ratio and packing of clay with $\mathrm{pH}$ for improved gas barrier in nanobrick wall thin films. ACS Applied Materials \& Interfaces, 6, 22914-22919.

Han, D., Luo, Y., Ju, Q., Xiao, X., Xiao, M., \& Xiao, N., et al. (2018). Nano-brick wall architectures account for super oxygen barrier pet film by quadlayer assembly of polyelectrolytes and $\alpha$-ZrP nanoplatelets. Polymers, 10, 1082.

Heo, J., Choi, M., \& Hong, J. (2019). Facile surface modification of polyethylene film via spray-assisted layer-by-layer self-assembly of graphene oxide for oxygen barrier properties. Scientific Reports, 9, 2754.

Herrera, M. A., Sirviö, J. A., Mathew, A. P., \& Oksman, K. (2016). Environmental friendly and sustainable gas barrier on porous materials: Nanocellulose coatings prepared using spin- and dip-coating. Materials and Design, 93, 19-25.

Huang, J.-Y., Li, X., \& Zhou, W. (2015). Safety assessment of nanocomposite for food packaging application. Trends in Food Science \& Technology, 45, 187-199.

InMat (2009). Ultrahigh barrier coating breakthrough from InMat ${ }^{\circledR}$ reduces food packaging costs and environmental impact. last access December 2019 http://www.inmat. com/upload/files/inmat_press_release_05072009.pdf.

Introzzi, L., Blomfeldt, T. O. J., Trabattoni, S., Tavazzi, S., Santo, N., \& Schiraldi, A., et al. (2012). Ultrasound-assisted pullulan/montmorillonite bionanocomposite coating with high oxygen barrier properties. Langmuir, 28, 11206-11214.

Iotti, M., Fabbri, P., Messori, M., Pilati, F., \& Fava, P. (2009). Organic-inorganic hybrid coatings for the modification of barrier properties of poly(lactic acid) films for food packaging applications. Journal of Polymers and the Environment, 17, 10-19.

Jang, W. S., Rawson, I., \& Grunlan, J. C. (2008). Layer-by-layer assembly of thin film oxygen barrier. Thin Solid Films, 516, 4819-4825.

Kaiser, K., Schmid, M., \& Schlummer, M. (2018). Recycling of polymer-based multilayer packaging: A review. Recycling, 3, 1. doi:10.3390/recycling3010001. 
Kumar, N., \& Sinha Ray, S. (2018). Synthesis and functionalization of nanomaterials. In Sinha Ray, S. (Ed.), Processing of polymer-based nanocomposites: Vol. 277 (pp. 15-55). Cham: Springer. Springer Series in Materials Science.

Li, F., Biagioni, P., Finazzi, M., Tavazzi, S., \& Piergiovanni, L. (2013). Tunable green oxygen barrier through layer-by-layer self assembly of chitosan and cellulose nanocrystals. Carbohydrate Polymers, 92, 2128-2134.

Lim, M., Kim, D., \& Seo, J. (2016). Enhanced oxygen-barrier and water-resistance properties of poly(vinyl alcohol) blended with poly(acrylic acid) for packaging applications. Polymer International, 65, 400-406.

Mascheroni, E., Rampazzo, R., Ortenzi, M. A., Piva, G., Bonetti, S., \& Piergiovanni, L. (2016). Comparison of cellulose nanocrystals obtained by sulfuric acid hydrolysis and ammonium persulfate, to be used as coating on flexible food-packaging materials. Cellulose, 23, 779-793.

Merritt, S. M. J., Wemyss, A. M., Farris, S., Patole, S., Patias, G., \& Haddleton, D. M., et al. (2020). Gas barrier polymer nanocomposite films prepared by graphene oxide encapsulated polystyrene microparticles. ACS Applied Polymer Materials. doi:10.1021/ acsapm.9b01041. (in press).

Minelli, M., De Angelis, M. G., Doghieri, F., Marini, M., Toselli, M., \& Pilati, F. (2008). Oxygen permeability of novel organic-inorganic coatings: I. Effects of organic-inorganic ratio and molecular weight of the organic component. European Polymer Journal, $44,2581-2588$

Minelli, M., De Angelis, M. G., Doghieri, F., Rocchetti, M., \& Montenero, A. (2010). Barrier properties of organic-inorganic hybrid coatings based on polyvinyl alcohol with improved water resistance. Polymer Engineering \& Science, 50, 144-153.

NanoPack (2012). NanoSeal ${ }^{\mathrm{TM}}$ - barrier coating, OPP barrier coated film, polypropylene film, liquid coating. http://www.nanopackinc.com/products.asp last access December 2019.

Naseer, B., Srivastava, G., Qadri, O. S., Faridi, S. A., Islam, R. U., \& Younis, K. (2018). Importance and health hazards of nanoparticles used in the food industry. Nanotechnology Reviews, 7, 623-641.

Nicole, L., Rozes, L., \& Sanchez, C. (2010). Integrative approaches to hybrid multifunctional materials: From multidisciplinary research to applied technologies. Advanced Materials, 22, 3208-3214.

Ntim, S. A., \& Noonan, G. O. (2017). Nanotechnology in food packaging. In Chaudhry, Q., Castle, L., \& Watkins, R. (Eds.), Nanotechnologies in foods (pp. 118-142). Cambridge, UK: The Royal Society of Chemistry.

Part, F., Berge, N., Baran, P., Stringfellow, A., Sun, W., \& Bartelt-Hunt, S., et al. (2018). A review of the fate of engineered nanomaterials in municipal solid waste streams. Waste Management, 75, 427-449.

Peters, R. J. B., Bouwmeester, H., Gottardo, S., Amenta, V., Arena, M., \& Brandhoff, P., et al. (2016). Nanomaterials for products and application in agriculture, feed and food. Trends in Food Science \& Technology, 54, 155-164.

Priolo, M. A., Gamboa, D., Holder, K. M., \& Grunlan, J. C. (2010). Super gas barrier of transparent polymer-clay multilayer ultrathin films. Nano Letters, 10, 4970-4974.

Priolo, M. A., Holder, K. M., Gamboa, D., \& Grunlan, J. C. (2011). Influence of clay concentration on the gas barrier of clay-polymer nanobrick wall thin film assemblies. Langmuir, 27, 12106-12114.

Rampazzo, R., Alkan, D., Gazzotti, S., Ortenzi, M. A., Piva, G., \& Piergiovanni, L. (2017). Packaging Technology and Science, 30, 645-661.

Richardson, J. J., Bjornmalm, M., \& Caruso, F. (2015). Technology-driven layer-by-layer assembly of nanofilms. Science, 348. aaa 2491.

Rodionova, G., Saito, T., Lenes, M., Eriksen, O., Gregersen, O., \& Fukuzumi, H., et al. (2012). Mechanical and oxygen barrier properties of films prepared from fibrillated dispersions of TEMPO-oxidized Norway spruce and Eucalyptus pulps. Cellulose, 19, 705-711.

Rovera, C., Ghaani, M., Santo, N., Trabattoni, S., Olsson, R. T., \& Romano, D., et al. (2018). Enzymatic hydrolysis in the green production of bacterial cellulose nanocrystals. ACS Sustainable Chemistry \& Engineering, 6, 7725-7734.

SAES Coated Films https://www.saescoatedfilms.com/en/transparent-oxygen/last access December 2019

Sanchez, C., Belleville, P., Popall, M., \& Nicole, L. (2011). Applications of advanced hybrid organic-inorganic nanomaterials: From laboratory to market. Chemical Society Reviews, 40, 696-753.

Sànchez, C., Hortal, M., Aliaga, C., Devis, A., \& Cloquell-Ballester, A. (2014). Recyclability assessment of nano-reinforced plastic packaging. Waste Management, 34, 2647-2655.
Sanchez, C., Rozes, L., Ribot, F., Laberty-Robert, C., Grosso, D., \& Sassoye, C., et al. (2010). "'Chimie douce'”: A land of opportunities for the designed construction of functional inorganic and hybrid organic-inorganic nanomaterials. Comptes Rendus Chimie, 13, 3-39.

Silvestre, C., Duraccio, D., \& Cimmino, S. (2011). Food packaging based on polymer nanomaterials. Progress in Polymer Science, 36, 1766-1782.

Smithers Pira The future of global packaging to 2022https://www.smithers.com/services/ market-reports/packaging/the-future-of-global-packaging-to-20222017last access: December 2019

Smithers Pira The future of European food \& drink packaging to 2023https://www. smithers.com/services/market-reports/packaging/european-food-and-drinkpackaging-to-20232018last access: December 2019

Song, Y., Tzeng, P., \& Grunlan, J. C. (2016). Super oxygen and improved water vapot barrier of polypropylene film with polyelectrolyte multilayer nanocoatings. Macromolecular Rapid Communications, 37, 963-968.

Sorrentino, A., Gorrasi, G., \& Vittoria, V. (2007). Potential perspectives of bio-nanocomposites for food packaging applications. Trends in Food Science \& Technology, 18, 84-95.

Störmer, A., Bott, J., Kemmer, D., \& Franz, R. (2017). Critical review of the migration potential of nanoparticles in food contact plastics. Trends in Food Science \& Technology, 63, 39-50.

Svagan, A. J., Åkesson, A., Cárdenas, M., Bulut, S., Knudsen, J. C., \& Risbo, J., et al. (2012). Transparent films based on PLA and montmorillonite with tunable oxygen barrier properties. Biomacromolecules, 13, 397-405.

Toselli, M., Pilati, F., Marini, M., Doghieri, F., De Angelis, M. G., \& Minelli, M. (2008). Oxygen permeability of novel organic-inorganic coatings: II. Modification of the organic component with a hydrogen-bond forming polymer. European Polymer Journal, 44, 3256-3263.

Tsurko, E. S., Feicht, P., Habel, C., Schilling, T., Daab, M., \& Rosenfeldt, S., et al. (2017). Can high oxygen and water vapor barrier nanocomposite coatings be obtained with a waterborne formulation? Journal of Membrane Science, 540, 212-218.

Tyagia, P., Lucia, L. A., Hubbe, M. A., \& Pal, L. (2019). Nanocellulose-based multilayer barrier coatings for gas, oil, and grease resistance. Carbohydrate Polymers, 206, 281-288.

Uysal Unalan, I., Boyaci, D., Ghaani, M., Trabattoni, S., \& Farris, S. (2016). Graphene oxide bionanocomposite coatings with high oxygen barrier properties. Nanomaterials, 6 , 244.

Uysal Unalan, I., Boyaci, D., Trabattoni, S., Tavazzi, S., \& Farris, S. (2017). Transparent pullulan/mica nanocomposite coatings with outstanding oxygen barrier properties. Nanomaterials, 7, 281.

Uysal Unalan, I., Cerri, G., Marcuzzo, E., Cozzolino, C. A., \& Farris, S. (2014). Nanocomposite films and coatings using inorganic nanobuilding blocks (NBB): Current applications and future opportunities in the food packaging sector. RSC Advances, 4, 29393-29428.

Vartiainen, J., Pasanen, S., Kenttä, E., \& Vähä-Nissi, M. (2018). Mechanical recycling of nanocellulose containing multilayer packaging films. Journal of Applied Polymer Science, 135,46237

Vartiainen, J., Tuominen, M., \& Nättinen, K. (2010). Bio-hybrid nanocomposite coatings from sonicated chitosan and nanoclay. Journal of Applied Polymer Science, 116, 3638-3647.

Verma, G. (2017). Polymer nanocomposites and coatings: The game changers. In Nayak, S. K., Mohanty, S., \& Unnikrishnan, L. (Eds.), Trends and applications in advanced polymeric materials (pp. 1-22). Hoboken, New Jersey: John Wiley and Sons, Inc.

Wong, M., Ishige, R., White, K. L., Li, P., Kim, D., \& Krishnamoorti, R., et al. (2014). Large-scale self-assembled zirconium phosphate smectic layers via a simple spray-coating process. Nature Communications, 5, 3589.

Yang, Y.-H., Haile, M., Park, Y. T., Malek, F. A., \& Grunlan, J. C. (2011). Super gas barrier of all-polymer multilayer thin films. Macromolecules, 44, 1450-1459.

Yu, J., Ruengkajorn, K., Crivoi, D.-G., Chen, C., Buffet, J.-C., \& O'Hare, D. (2019). High gas barrier coating using non-toxic nanosheet dispersions for flexible food packaging film. Nature Communications, 10, 2398.

Zhang, X., Xu, Y., Zhang, X., Wu, H., Shen, J., \& Chen, R., et al. (2019). Progress on the layer-by-layer assembly of multilayered polymer composites: Strategy, structural control and applications. Progress in Polymer Science, 89, 76-107. 